\title{
Socialization of Lupus Disease Awareness for Housewife Group of Genting Village, Ambarawa, Central Java
}

\author{
Stalis Norma Ethica ${ }^{1}$, Ayu Rahmawati Sulistyaningtyas², \\ Aditya Rahman Ernanto², Muhammad Ardi Afriansyah², \\ Ana Hidayati Mukaromah ${ }^{2}$ \\ 1,2 Universitas Muhammadiyah Semarang, Indonesia
}

\begin{abstract}
A B S T R A C T
Lupus or Systemic Lupus Erythematosus (SLE) is a life-threatening chronic autoimmune disease with symptoms similar to those of other diseases. Frequent misdiagnosis of lupus increases the mortality rate of the disease. Public understanding is still low about Lupus, characterized by a variety of misperceptions about the disease, which still occurs. In rural area, Lupus is still often regarded as a virus transmitted and is associated with weak immune activity. There are still many women who do not yet know that they are a group that is more susceptible to Lupus than men. Various errors in people's perception of Lupus need to be corrected to increase public awareness of the disease. Efforts to correct misperceptions about Lupus have been done through Science and Technology for Community (Ilmu Pengetahuan dan Teknologi bagi Masyarakat, IbM) activities in counseling form to the housewife groups in Kalipucung Hamlet, Genting Village, Jambu District, Ambarawa, Central Java. Participatory approaches and tutorials have been carried out in the $\mathrm{IbM}$ activities through the provision of counseling materials, as well as the delivery of questionnaires before and after counseling. The results of the questionnaire analysis indicate that the counseling program could improve awareness about Lupus disease among community in rural area.
\end{abstract}

\begin{tabular}{llrl} 
Keywords: & \multicolumn{2}{c}{$\begin{array}{l}\text { Autoimmune Disease, Genting Village, Housewife, Lupus Awareness, } \\
\text { Science and Technology for Society. }\end{array}$} \\
\hline Received: & Revised: & Accepted: & Available online: \\
21.02 .2020 & 08.06 .2020 & 14.08 .2020 & 30.11 .2020 \\
\hline
\end{tabular}

\section{Suggested citation:}

Ethica, S. N., Sulistyaningtyas, A. R., Ernanto, A. R., Afriansyah, M. A., \& Mukaromah, A. H. (2020). Socialization of lupus disease awareness for housewife group of Genting Village, Ambarawa, Central Java. Jurnal Pengabdian Pada Masyarakat, 5(4), 906-916. https://doi.org/10.30653/002.202054.444

Open Access I URL: http://ppm.ejournal.id/index.php/pengabdian/article/view/444

\footnotetext{
${ }^{1}$ Corresponding Author: Medical Laboratory Science, Master Program, Universitas Muhammadiyah Semarang, Jl. Kedungmundu Raya No. 18 Semarang, 50273, Indonesia. Email: norma@unimus.ac.id
} 


\section{INTRODUCTION}

Lupus or Systemic Lupus Erythematosus (SLE, Lupus) is a life-threatening chronic autoimmune disease. The disease is characterized by a complex pathogenesis along with episodes of remissions and relapses and remissions. Lupus is closely associated with functional disability, including cognitive impairment, debilitating fatigue, severe articular involvement, as well as chronic renal disease. Today, there are an estimated 1.5 million people living with Lupus. Symptoms of Lupus vary; some of which resemble those of other diseases, which often cause misdiagnosis. It is among the factors causing the high mortality rate of Lupus (Sullivan, 2016; Etchegaray-Morales et al., 2017)

Aside of frequent misdiagnosis of Lupus increasing the mortality rate of the disease, public understanding is still low about the disease in Indonesia and other countries such as Mexico and Saudi Arabia. Such poor understanding is characterized by a variety of misperceptions about the disease, which still occurs. In rural area, Lupus is still often regarded as a virus transmitted and is associated with weak immune activity. There are still many women who have not yet realized that they are a group that is more susceptible to Lupus. Various errors in people's perception of Lupus need to be corrected to increase public awareness of the disease (Rohmatillah, 2018; Gladman, 2017; Sullivan, 2016; Etchegaray-Morales et al., 2017; Alharby et al., 2018). Raising public awareness could improve awareness of caregiver and reduce stigma of Lupus. Improving family education at diagnosis holds is expected to raise patient-physician trust and omit fear. Education materials for primary care providers at initial point of contact with the health care system could improve early recognition of Lupus and provide expedited referral to a specialist (Lewandowsky et al., 2017).

Lupus generally attacks the productive age group and often drastically lowers the economic level of people with Lupus (Odapus) and their families. Even so, Odapus still has hopes of getting near normal or remission conditions, the condition with controlled symptoms of Lupus even without consuming the main drugs at all. Encouragement and enthusiasm from the people around them and various community efforts to increase the spirit of life and productivity are very necessary for Odapus to be able to control their diseases (Tunnicliffe et al., 2018; Utset et al., 2015).

The Medical Laboratory Science and Technology Study Program at Universitas Muhammadiyah Semarang (UNIMUS) is one of Indonesian higher education institutions aiming to generate skillful health analyst experts. UNIMUS is located in Kedungmundu District, Semarang City, Central Java Province. At present UNIMUS has a quite large academic community consisting of 4000-5000 people including students. The role of UNIMUS in promoting health education for the surrounding community is highly expected. Participation of UNIMUS Medical Laboratory Science and Technology academicians in delivering education related to particular diseases such as Lupus is very appropriate. With their scientific background, UNIMUS Medical Laboratory Science and Technology academicians have opportunity to make positive changes in the community, especially in improving perceptions of Lupus. The correct perception of Lupus will gradually increase Indonesian people awareness of the disease. This ultimately will help to prevent late Lupus treatment or misdiagnosis, which could indirectly reduce the mortality rate of Lupus in the community. 
Public understanding of Lupus is still low as evidenced by the many cases of misperception of Lupus. Counselling activities on the importance of early detection of lupus are expected to be an effective way for socializing Lupus with the aims of: 1 . Educating the public to increase awareness of Lupus, especially in women who are more vulnerable to Lupus; 2 . Delivering immunological science, which related to immune abnormalities in Lupus patients to the public in order to understand the factors that cause Lupus; 3 . Helping to straighten out the wrong myths about Lupus, especially to encourage facts that Lupus is actually not contagious; 4 . Encourage people who have gained knowledge about Lupus to pass on the correct information about the disease. All goals that have been set are expected also to improve the quality of public health and provide space for Lupus sufferers to get a better reception space from the public regarding their health conditions.

In order to reach the goals, specific group of women living in rural area in Central Java could be targeted as the participants to receive the counseling. Rural area should be the priority to conduct the counseling, since in such area, there has been limited access on information about Lupus. Housewives from the community of Kalipucung Hamlet, Genting Village, Jambu sub-district, Ambarawa, Semarang Regency apparently meet the criteria of targeted participants of Lupus counselling program. The group of women generally have low education (most of them receive elementary education in maximum). Previously they had never participated in any form of counseling related with Lupus.

The implementation of Lupus awareness as part of community service activities ideally involve university students, so they could learn how to accept full responsibility and could experience in providing community services activities. The participatory approach and tutorial could be suitable way to carried out the planned community service activity by involving government elements of the village of rural area and also UNIMUS institution. The method to be carried out includes the provision of counselling materials, delivery of questionnaires and analysis of the results of counselling in graphical form.

Systemic Lupus Erythematosus (SLE) is the prototypical systemic autoimmune disease, characterized by hyperactive immune cells and antibody production. Immunologic abnormalities, particularly the production of a number of antinuclear antibodies, are another prominent feature of the disease. Lupus is a chronic inflammatory disease that could affect virtually every organ. Women are affected by Lupus more frequently than men with a ratio of 9:1 (Gladman, 2017; Luo \& Husen, 2017; Yan et al., 2012; Maselli et al., 2016). Though rare, however, male Lupus patients, developed more severe symptoms with neuro- psychiatric, renal, cardiovascular, peripheral vascular diseases, and myocardial infarction (Shirai et al., 2017)

Although the causes of Lupus have not been fully understood, yet generally environmental factors such as stress, food, antibiotics, infections, ultraviolet light exposure, and the use of drugs could worsen symptoms of this disease (Kinsey et al., 2018; Wallace et al., 2011). Infections could act as environmental triggers that induce or promote Lupus in genetically predisposed individuals. However, Lupus itself is not a contagious or infectious disease (Rasmussen et al., 2015; Kristanto \& Harry, 2017). 
The most common symptoms experienced by people with Lupus (Odapus) are chronic inflammation and hemolytic anemia. Besides, due to the side effects of some of the main types of drugs consumed, Odapus generally also suffers from osteoporosis. In order for Lupus to be controlled, Odapus are required to maintain a healthy diet and implement proper stress management. To control Lupus, Odapus are required to have high discipline in avoiding factors aggravating Lupus symptoms. In addition, Lupus sufferers must avoid direct contact with UV light and consume drugs prescribed regularly by the doctors (Farkhati et al., 2012).

Lupus is a disease with substantial direct and indirect costs over the lifespan of patients and with well-known health disparities. Significant health disparities, which include higher renal complications and mortality rates, have been noted in groups defined by low socioeconomic status, black race, Hispanic ethnicity, or Asian ethnicity (Reed, 2017).

The psychological consequences of an SLE diagnosis result in increased daily stress, anticipated stigma, fears of rejection, and increased self-consciousness, all of which could decrease a patient's quality of life. Misperceptions of Lupus disease and mood disorders caused by poor quality of life in case of Mexican patients deteriorate the prognosis and treatment adherence. In order to combat these negative experiences, attempts to increase accurate knowledge of Lupus and extinguish misconceptions about the disease must be made (Etchegaray-Morales et al., 2017; Sullivan, 2016).

There is increasing recognition that academic and community collaborations enhance the provision of human services and resources. Recently, a case of successful collaboration between academics at Long Island University (LIU) and a Lupus care organization in the community, The Lupus Alliance of America, Inc. (LAA) had been reported. It was found that opportunities for these partnerships are enhanced when faculty members are already engaged in community-based activities (Giffords \& Calderon, 2015). Based on this, in Indonesia could adopt such collaboration system to spread Lupus awareness. The health academicians should be engaged in community based activities, particularly in the success of health promotion associated with Lupus.

\section{METHOD}

This community service had been done in 19 February - 30 March in 2018, located in Kalipucung Hamlet, Genting Village, Jambu District, Ambarawa, Semarang, Central Java Province (Figure 1).

The participatory and counseling approach had been carried out in this community service by involving local government elements at the village and college level. Implementation method that had been done includes the provision of counseling materials, delivery of questionnaires and analysis of the results. The workflow of activities was as shown in Figure 2. 


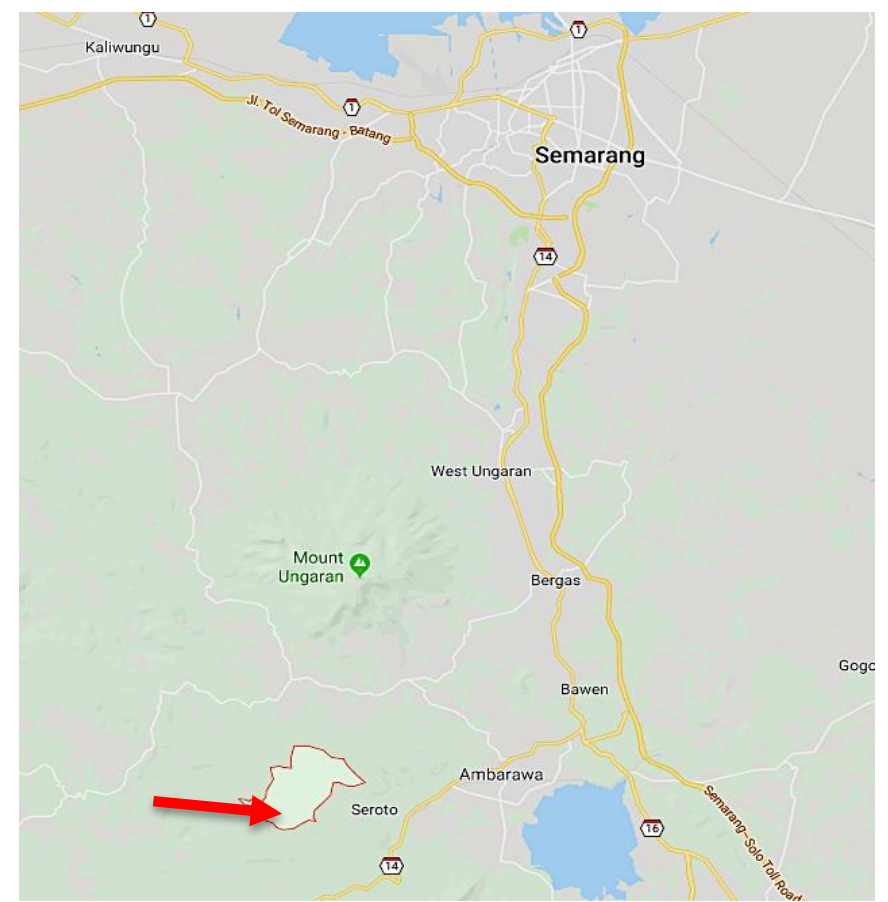

Figure 1. Genting Village (red arrow) where the IbM activity had been conducted

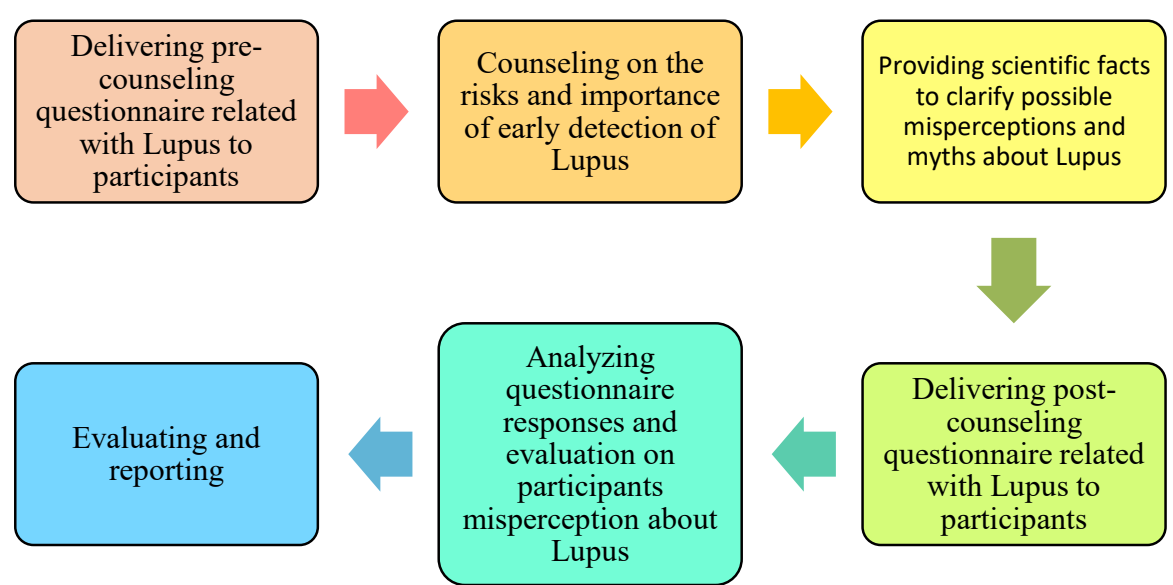

Figure 2. Workflow of counseling activity to correct misperception of Lupus disease

Every participant was provided with a piece of paper containing separated questionnaire, intended to be filled before and after counseling. The questions and options of answers in both pre- and post-questionnaire are similar, including 3 most common misperceptions about Lupus disease shown by Figure 3 . 


\section{KUESIONER:}

Iptek Bagi Masyarakat: Penyuluhan Pentingnya Deteksi Dini Penyakit Lupus

\section{Sebelum Penyuluhan}

1. Apa yang dimaksud dengan penyakit Lupus? Pilih jawaban yang benar

a. Penyakit akibat infeksi virus

b. Penyakit akibat sistem imun yang hiperaktif

c. Penyakit akibat sistem imun yang lemah

2. Penyakit Lupus lebih banyak menyerang kelompok mana? Pilih jawaban yang benar:
a. Wanita
b. Pria

3. Apakah penyakit Lupus bersifat menular? Pilih jawaban yang benar:
a. Ya
b. Tidak

\section{Setelah Penyuluhan}

1. Apa yang dimaksud dengan penyakit Lupus? Pilih jawaban yang benar
a. Penyakit akibat infeksi virus
b. Penyakit akibat sistem imun yang hiperaktif
c. Penyakit akibat sistem imun yang lemah

2. Penyakit Lupus lebih banyak menyerang kelompok mana? Pilih jawaban yang benar:
a. Wanita
b. Pria

3. Apakah penyakit Lupus bersifat menular? Pilih jawaban yang benar:
a. Ya
b. Tidak

Figure 3. Three main questions related with Lupus disease awareness in each questionnaire delivered to each counseled participant before and after counselling session

Data obtained from pre- and post-questionnaire were then compared and displayed in a simple bar chart using MS Excel.

\section{RESULT AND DISCUSSION}

Community service activity through counseling themed "The Importance of Early Detection of Lupus". In rural area of Central Java reported in this paper had been conducted during February 19 to March 30 in 2018. Participants of the counseling program were 29 housewives aged 23-65 with junior high school as highest education level, and had never been receiving any counseling related with awareness of Lupus and other auto-immune diseases.

Planning of this community service activity at Genting Village, Jambu Sub-District, Ambarawa, Semarang Regency ranging from correspondence and preparation to core events took up to 3 weeks. Preparation of the initial activities was carried out by 
conducting surveys at several locations in Genting Village, supported by Medical Laboratory Technology students who also had been working during the IbM activity on Real Work Study (Kuliah Kerja Nyata KKN) Program in the same location. It was also aimed to meet local community leaders to submit plans for extension activities and to offer the idea of probable extension activities. The achieved agreements include:

1) UNIMUS Lecturer and Student as a team led by the Lupus counselor, Dr. Stalis Norma Ethica, M.Si. from the UNIMUS Medical Laboratory Science/ Technology Study Program were the proposer and implementer responsible for coordinating the implementation of core events and extension materials.

2) The community, namely the housewife group (Ibu Rumah Tangga, IRT) of Genting Village in Jambu District, Ambarawa provided location and accommodation for counseling activities at the residence of Mrs. Fitrianingsih as the Chairperson of the group.

3) The participants of the event mainly came from IRT of Genting Village in Jambu District, Ambarawa including students who also worked as committee members.

4) Students are directly involved in activities and given responsibility for preparing banners and conducting documentation of activities.

5) Dr. Stalis Norma Ethica was asked to be the chief executive as well as a resource person for counseling activities themed "The Importance of Early Detection of Lupus".

The implementation of socialization activities is carried out by following the procedures for implementing the activities planned according to the chart in Figure 2. Main counseling event had been carried out at the set location on Tuesday, February 20, 2018. Opening of the event was conducted by head of study program of UNIMUS Medical Laboratory Science/ Technology. Next, distribution of pre-questionnaires to find out basic knowledge of participants was carried out before delivering material on counseling about the definition of Lupus and the importance of early Lupus detection (Figure 4 and 5).

Printed materials presented in the counselling events were distributed to all participants. Printed materials were used because due to facility limitations in rural area, it was not possible to utilize any multimedia facilities. During counseling, the speakers invited participants to take part in the discussion. Participants are free to articulate their opinions or comments throughout the session. For participants who contributed their questions or opinions, souvenirs in the form of hats and books were given as awards. The activity was continued with evaluation of case studies involving participants, ended with the distribution of questionnaires on the same day. The series of activities were then followed with an evaluation of the results of the questionnaire delivered in the form of the final report of the activity.

Based on evaluation, it was found that the activities held were a happy moment for the community of the housewife group of Genting Village because they could gather and get knowledge as well as motivation to convey the true facts regarding Lupus. Other happiness that came from participants who actively participated in the discussion received awards for their activeness in the form of hats and books (Figure 6). Based on the results of the evaluation activities, information was obtained that participants hoped that similar extension activities could continue to be provided with other extension materials, and even other events in the future. 


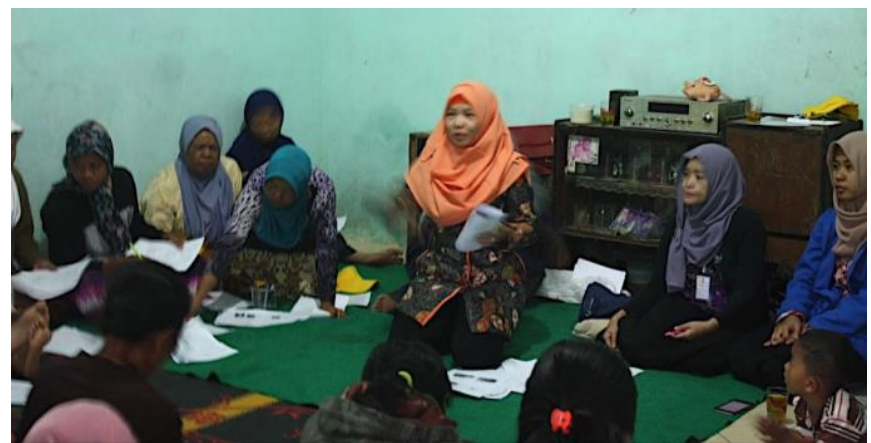

Figure 4. Pre-questionnaire activity before counseling presentation

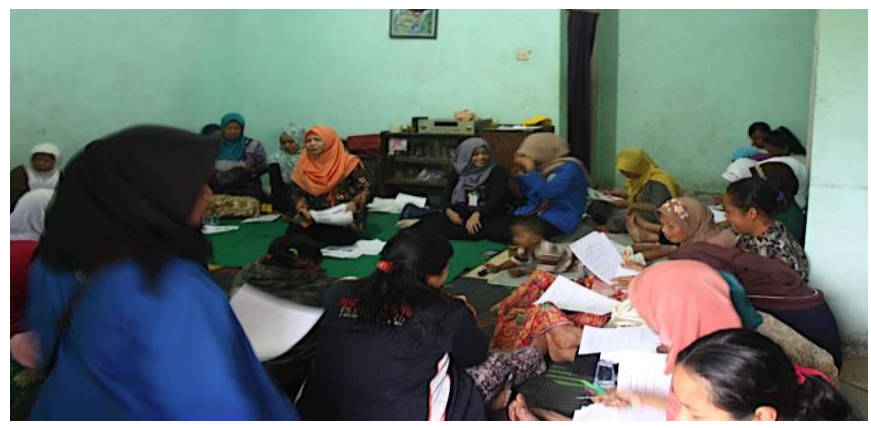

Figure 5. Delivery of post-questionnaire after counseling presentation

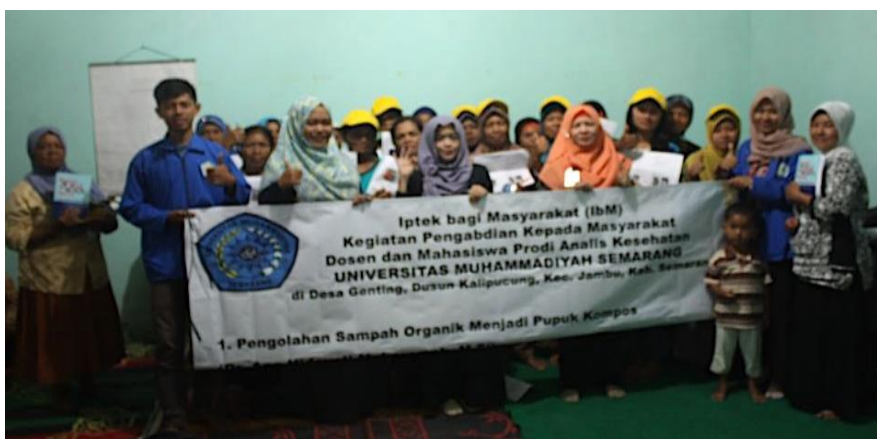

Figure 6. Awarding hats and books to most active participants in closing ceremony

The evaluation was not only conducted to determine the quality of the implementation of the activities, but also to find out whether there was an increase in people's understanding of Lupus according to the counseling materials provided. Analysis of the results of the questionnaire analysis was conducted at the beginning of March 2018.

The IbM activity through counseling with the theme of "Pentingnya Deteksi Dini Penyakit Lupus" (Importance of Early Detection of Lupus) was intended to improve understanding of the housewife in the village about Lupus. The understanding was measured through analysis of questionnaire answers provided before and after counseling activities. The questionnaire mainly focused on basic causes of Lupus and its relation with the immune system, the groups susceptible to the disease, the facts about Lupus transmission. The improvement measured by questionnaire analysis before and 
after counseling had given. The results of the analysis of the questionnaire responses received from participants before and after counseling are shown in Figure 8. There were 29 participants following IbM counseling activity, yet only 21 could manage to return questionnaire responses.

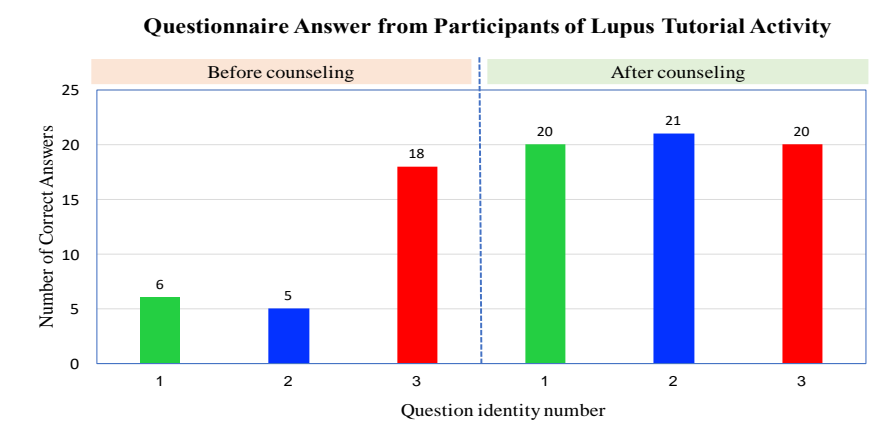

Figure 7. Improved perception showed by more correct answers among housewife group about Lupus disease after counseling

Figure 7 shows comparison between the pre- and post-questionnaire answers coming from 21 participants. Before counseling, participants that answer correctly question with identity number of 1,2 and 3 were $29 \%, 24 \%$, and $86 \%$ respectively. After counseling, there were improvement where the number of correct answer reached $95 \%$, $100 \%$, and $95 \%$ respectively.

In general, the results show the improvement understanding of participants about Lupus disease. There are 66\% improvement understanding in participants that Lupus was a disease caused by immune hypersensitivity, or Lupus was not caused by decrease of immunity or disease manifestation of virus infection. There was $76 \%$ improvement in understanding the fact that Lupus is more common in women than men. The $9 \%$ improvement in the perception of participants, where they did not see Lupus as contagious or infectious disease.

General increased number of correct answers were observed for all questions addressed to counseling participants after counseling session. Such results could be seen as successful correction on previous misperception that participants have about Lupus in relation with the immune system, the groups susceptible to the disease, as well as the facts about Lupus transmission. Based on the results, scientific counseling activities conducted for the community resulted in correction of misperception about Lupus disease among housewife group in Genting Village.

\section{CONCLUSION}

Counseling activity of "Pentingnya Deteksi Dini Penyakit Lupus" for housewife group in Kalipucung Hamlet, Genting village, Kecamatan Jambu, Ambarawa, Central Java Province had been successfully done. The activity resulted in correction of common misperception about Lupus disease in terms of susceptibility, cause and transmission of the disease among housewife group in Genting Village. 


\section{Acknowledgement}

The authors wish to thank Mrs. Fitrianingsih for her guidance and housewife groups (IRT) of Genting Village, Jambu District, Ambarawa, Semarang, Central Java as partner of the conducted community service. We also thank to LPPM UNIMUS for financial support provided to carry out and publish this community service activity.

\section{REFERENCES}

Alharbi, M. D., Aljohani, B. O., Alaithan, Z. N., Alsamadani, S. K., Alnefaie, S. A., Alshabibi, A. I., .. \& Almuawi, M. M. (2018). Public awareness of systemic lupus erythematosus in Al-Dammam City in Saudi Arabia. The Egyptian Journal of Hospital Medicine, 70(11), 1891-1894.

Etchegaray-Morales, I., Méndez-Martínez, S., Jiménez-Hernández, C., Mendoza-Pinto, C., Alonso-García, N. E., Montiel-Jarquín, A., ... \& García-Carrasco, M. (2017). Factors associated with health-related quality of life in Mexican lupus patients using the LupusQol. PloS one, 12(1), e0170209.

Farkhati, M. Y., \& Sunartini Hapsara, S. C. (2011). Survival and prognostic factors of systemic lupus erythematosus. In Proceedings of Congress of Indonesian Pediatrics Society (pp. 236-42).

Giffords, E. D., \& Calderon, O. (2015). Academic and community collaborations: An exploration of benefits, barriers and successes. Human Service Organizations: Management, Leadership \& Governance, 39(4), 397-405. https://www.tandfonline.com/doi/abs/10.1080/23303131.2015.1034907

Gladman, D. D. (2017). Overview of the clinical manifestations of systemic lupus erythematosus in adults. Retrieved September 22, 2019 from https://tinyurl.com/y5ku4tvy

Kinsey, D., Paul, C. P., Taylor, D., Caricchio, R., Kulathinal, R. J., \& Hayes-Conroy, A. (2018). The whole lupus: Articulating biosocial interplay in systemic lupus erythematosus epidemiology and population disparities. Health $\mathcal{E}$ Place, 51, 182-188.

Kristanto, A. W., \& Hary, T. P. (2017). Motivasi hidup pada penderita lupus dewasa. Jurnal Spirits, 5(2), 1-6.

Lewandowski, L. B., Watt, M. H., Schanberg, L. E., Thielman, N. M., \& Scott, C. (2017). Missed opportunities for timely diagnosis of pediatric lupus in South Africa: a qualitative study. Pediatric Rheumatology, 15(1), 1-9.

Luo, X., \& Husen, Z. (2017). 354 A comparative analysis of gut microbiota between systemic lupus erythematosus patients and non-autoimmune controls: a single centrecenter cohort experience.

Maselli, A., Conti, F., Alessandri, C., Colasanti, T., Barbati, C., Vomero, M., ... \& Valesini, G. (2016). Low expression of estrogen receptor $\beta$ in T lymphocytes and high serum levels of anti-estrogen receptor $\alpha$ antibodies impact disease activity in female patients with systemic lupus erythematosus. Biology of Sex Differences, 7(1), 1-10. 
Rasmussen, N. S., Draborg, A. H., Nielsen, C. T., Jacobsen, S., \& Houen, G. (2015). Antibodies to early EBV, CMV, and HHV6 antigens in systemic lupus erythematosus patients. Scandinavian Journal of Rheumatology, 44(2), 143-149.

Reed, J. C. (2017). The Annual report of the Georgia council on lupus education and awareness for fiscal year ending June 30, 2017 (Doctoral dissertation). Department of Community Health Dr. S. Sam Lim, Emory University.

Rohmatillah, W. S. (2018). Hubungan antara penerimaan diri dan dukungan sosial dengan health belief pada penderita penyakit lupus (ODAPUS) (Doctoral dissertation). UIN Sunan Gunung Djati Bandung. http://digilib.uinsgd.ac.id/11125/

Shirai, H., Shoda, H., Kobayashi, S., Fujio, K., Setoguchi, K., \& Yamamoto, K. (2017). Two cases of very elderly onset male lupus patient; the characteristics and sex differences of elderly onset systemic lupus erythematosus patients. Modern Rheumatology Case Reports, 1(2), 84-88.

Sullivan, S. (2016). Development of a systemic lupus erythematosus knowledge questionnaire: the relationship among disease proximity, educational exposure and knowledge. Milwaukee, WI: UWM Digital Commons University of Wisconsin Milwaukee.

Tunnicliffe, D. J., Singh-Grewal, D., Craig, J. C., Jesudason, S., Tugwell, P., Lin, M. W., ... \& Tong, A. (2018). Perspectives of Medical Specialists from Different Disciplines on the Management of Systemic Lupus Erythematosus: An Interview Study. Arthritis Care \& Research, 70(9), 1284-1293.

Utset, T. O., Baskaran, A., Segal, B. M., Trupin, L., Ogale, S., Herberich, E., \& Kalunian, K. (2015). Work disability, lost productivity and associated risk factors in patients diagnosed with systemic lupus erythematosus. Lupus Science \& Medicine, 2(1), 1-9.

Wallace, D. J. S. V., Furie, V., Petri, R., Kalunian, M., Pike, K., \& M Kelley, L. (2011). Evaluation of Treatment Success in Systemic Lupus Erythematosus Clinical Trials: Development of the British Isles Lupus Assessment Group-based Composite Lupus Assessment Endpoint. Arthritis \& Rheumatism, 63, S894.

Yan, D., Jing, H., Guo, J. P., Dai, Y. J., Chun, L., Min, F., ... \& Li, Z. G. (2012). Gender differences are associated with the clinical features of systemic lupus erythematosus. Chinese Medical Journal, 125(14), 2477-2481.

\section{Copyright and License}

This is an open access article distributed under the terms of the Creative Commons Attribution 4.0 International License, which permits unrestricted use, distribution, and reproduction in any medium, provided the original work is properly cited. (C) 2020 Stalis Norma Ethica, Ayu Rahmawati Sulistyaningtyas, Aditya Rahman Ernanto, Muhammad Ardi Afriansyah, Ana Hidayati Mukaromah. 